\title{
Archaeological Investigations of Portions of the San Pedro and Alazan Acequias in San Antonio, Texas
}

Anne A. Fox

Follow this and additional works at: https://scholarworks.sfasu.edu/ita

Part of the American Material Culture Commons, Archaeological Anthropology Commons, Environmental Studies Commons, Other American Studies Commons, Other Arts and Humanities Commons, Other History of Art, Architecture, and Archaeology Commons, and the United States History Commons

Tell us how this article helped you.

This Article is brought to you for free and open access by the Center for Regional Heritage Research at SFA ScholarWorks. It has been accepted for inclusion in Index of Texas Archaeology: Open Access Gray Literature from the Lone Star State by an authorized editor of SFA ScholarWorks. For more information, please contact cdsscholarworks@sfasu.edu. 
Archaeological Investigations of Portions of the San Pedro and Alazan Acequias in San Antonio, Texas

\section{Creative Commons License}

\section{(c) (1) \&}

This work is licensed under a Creative Commons Attribution-NonCommercial 4.0 International License 


\title{
ARCHAEOLOGICAL INVESTIGATIONS OF PORTIONS OF THE \\ SAN PEDRO AND ALAZAN ACEQUIAS \\ IN SAN ANTONIO, TEXAS
}

\author{
Anne A. Fox
}

Center for Archaeological Research The University of Texas at San Antonio

Archaeological Survey Report, No. 49

1978 
Acknowledgments. .................. . . . $i j$ Introduction ...................... 1 A Brief History. ..................... . T The 01d Arsenal

Investigations. ................. 3 observations.................. 7 San Pedro Park

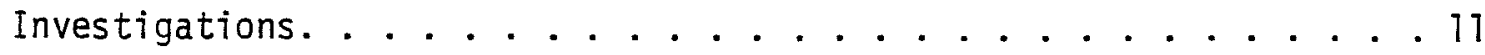
observations. . . . . . . . . . . . . . . 11 Conclusions and Recommendations. . . . . . . . . . . . 13 References cited ................... . 13

\section{LIST OF FIGURES}

Figure

1. Map of San Pedro and Alazan Acequias ............ . 2

2. San Pedro Acequia on Grounds of 01d Arsenal. . . . . . . . . . . 4

3. San Pedro Acequia, Area B. ............... 5

4. San Pedro Acequia, Area B Excavations. . . . . . . . . . . . 6

5. San Pedro Acequia, Area E. . . . . . . . . . . . 8

6. San Pedro Acequia, Area E Excavations. . . . . . . . . . . 9

7. San Pedro Acequia, Area F. . . . . . . . . . . . . 10

8. Alazan Acequia . . . . . . . . . . . . . . . 12 


\section{ACKNOWLEDGMENTS}

Many people contributed to the success of these projects. Dr. Thomas R. Hester, Director of the Center for Archaeological Research, served as Principal Investigator. Ronald Darner, Director of the San Antonio Parks and Recreation Department, was instrumental in recognizing the importance of the acequias and arranging for the work to be done. Patricia osborne, City Historic Preservation Officer, was most helpful in providing information and support.

On the Arsenal project, we are indebted to George Thomas, Construction Foreman for the McGinnis Company, who made us feel welcome and helped expedite the work in many ways. Project Architect Bert Whiteaker provided drawings and historical information. Architect Frank Valdez kindly allowed us to copy old maps of the Arsenal which he had in his files. John Nester of the D'Hanis Brick Company generously shared his knowledge of the company's history. The archaeological crew consisted of Shirley Van der Veer, Elizabeth Frkuska and Augustine Frkuska.

On the San Pedro Park project, Parks Superintendent Ed Davis secured and directed the backhoe operation. Architect Joe Stubblefield provided a copy of drawings for the landscaping project. 


\section{INTRODUCTION}

In the spring of 1977 the Center for Archaeological Research was requested by Ronald Darner, Director of the San Antonio Parks and Recreation Department, to investigate and record sections of the old acequias, or irrigation ditches, which were involved in renovation and landscaping projects in city parks. The purpose of this report is to present the information gained in this endeavor in lasting and usable form for the future benefit of historians and archaeologists working with these unique and interesting structures.

Since time and space do not allow an exhaustive discussion of the acequia system of San Antonio, the reader is referred to a number of other works which treat the subject in considerable detail, such as A Brief on the Acequias of San Antonio, compiled by Minor and Steinberg (1968); Holmes' thesis, The Acequias of San Antonio (1962); and Arneson's article, "Early Irrigation in Texas" (1921); as well as the section on acequias in William Corner's book, San Antonio de Bexar (1890). The only other professional archaeological excavations which have been done in San Antonio acequias were those of the Witte Memorial Museum in two different sections of the Alamo, or Valero, acequia during 1966 (Schuetz 1970) and a brief excavation adjacent to this same acequia within the Alamo grounds by The University of Texas at San Antonio in 1973 (Adams and Hester 1973).

\section{A BRIEF HISTORY}

When the Spanish missionaries and soldiers arrived to settle on San Pedro Creek in 1718, one of their primary concerns was to plant and harvest a crop to insure the survival of the settlement through the following winter. The first order of business, therefore, was to lay out and construct canals or acequias to irrigate their farm lands (Castañeda 1936:96). Theories abound but facts are few to substantiate which of the numerous acequias in the San Antonio area was constructed first. It seems likely that the first acequia may have been begun by the handful of settlers who were living in the area before the arrival of the 1718 caravan (Chabot 1937:91). Since the first settlement and farm lands were just south of San Pedro Springs (Barnes 1910:93; Crook 1967:97), their first irrigation ditch may have later become the San Pedro acequia, which ran south from the springs through the main part of the town, in front of San Fernando church, and on south to join the San Antonio River below the town (Fig. 1). This acequia was intended for the use of settlers on the west side of the river and was the principal source of drinking water for the townspeople, the San Antonio River and San Pedro Creek being reserved for bathing and washing (Corner 1890:105).

Throughout the Spanish period, the use and care of the acequias were administered by the local inhabitants, under a system dictated by Spanish law. During revolutionary times in the early 19 th century, the system fell into disrepair. The city took charge of the acequias in 1858 (Corner 1890:50) and hired Jacob Wurzbach, a civil engineer for the German Emigration Society, to clean out, reopen and administer the Spanish ditches (Chabot 1937:406). When the United States Army acquired a large section of farm land south of the center of town 


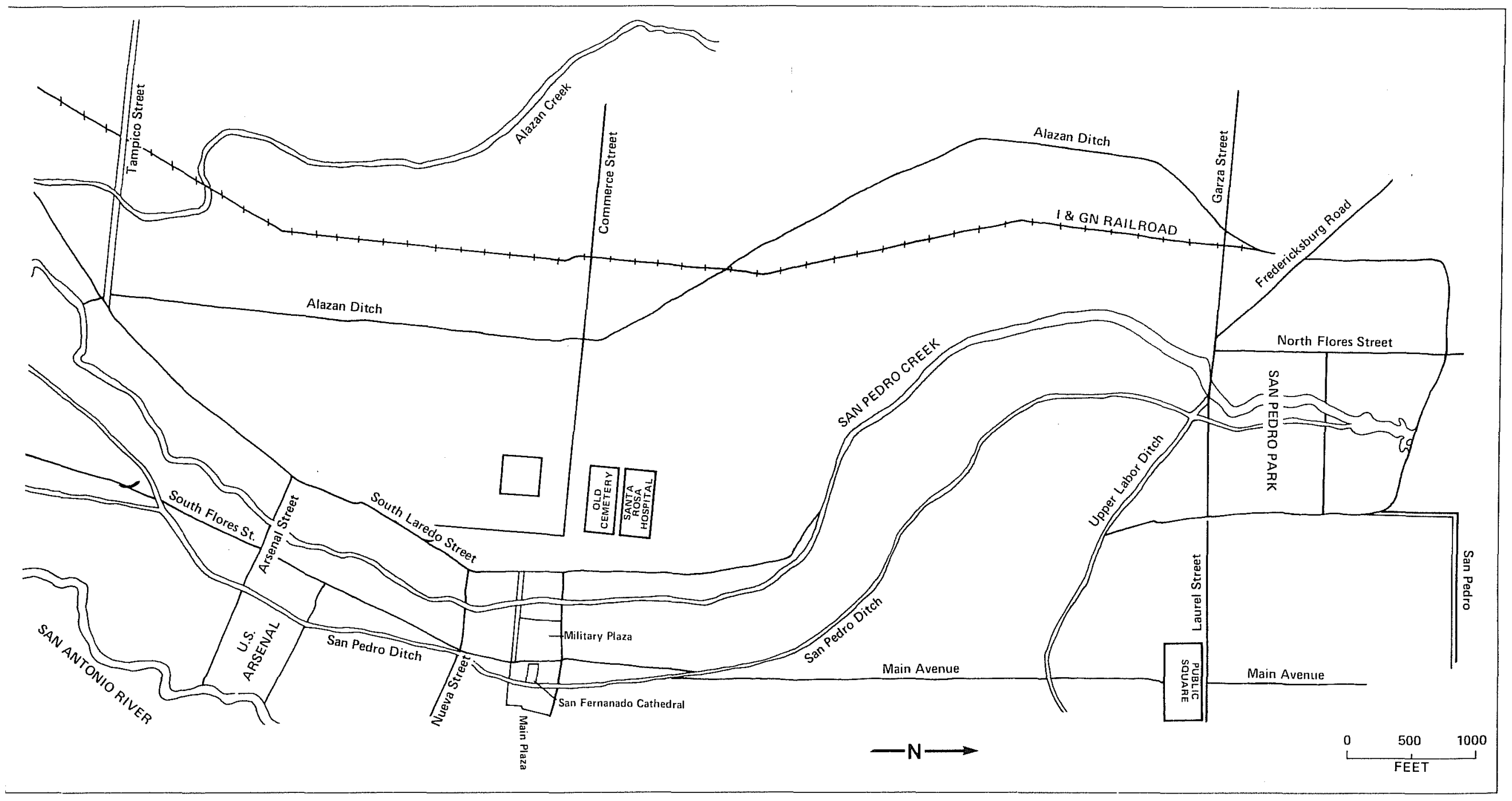

Figure 1. Map of San Pedro and Alazan Acequias. 
to build an arsenal in 1859 (Heusinger 1951:27), a section of the San Pedro acequia was still open and in operation across the property.

As the population grew and the town expanded, demands for farm lands naturally increased, and by the mid-19th century the city, by then predominantly AngloAmerican, had decided to construct an acequia similar to those built by the Spanish in order to water the lands west of San Pedro Creek. In 1872 the City Engineer, Francois Giraud, drew up plans for the project, and work was begun on the Alazan acequia. The object was to pick up water from the Upper Labor acequia, which had been constructed by the Spanish settlers 100 years previously (Corner 1890:46-49), and route this water around the head of the San Pedro Springs and into the valley of the Alazan Creek to the west (Fig. 1). By 1890 William Corner observed, "The Alazan was a bold and practical conception, but the work seems to have been inadequately done" (1890:50). With the growth of the city, the farm lands were gradually taken over by homes and businesses until the need for the acequia was eliminated, and it was filled in and forgotten by 1900 .

Despite the construction from 1880 to 1890 of numerous wells and a water system (McLean 1924:4-8), the San Pedro acequia stayed open until 1906 when the water was finally cut off. After that time, the old acequia walls were gradually buried beneath the growing and expanding city and were for the most part forgotten, until the construction of Hemisfair in 1966 exposed a section of the old Alamo acequia and called attention to these long-neglected structures (Schuetz 1970).

Investigations at the 01d Arsenal

In February 1977, a crew from the Center for Archaeological Research undertook to uncover portions of the walls of the section of the San Pedro acequia which runs through the grounds of the Commander's House, in order to prepare a map of this part of the acequia and to record as much detail as possible of its construction. As work progressed, a surprising amount of information was obtained from this one small fragment of the acequia.

The first area examined (Fig. 2, Area A) was a section of the acequia which had been exposed in a plumbing trench. At this point the acequia measures $150 \mathrm{~cm}$ in width, with cut-stone wal1s 50 to $60 \mathrm{~cm}$ in thickness.

Following the line of the ditch to the north, Area $B$ was opened up to expose the west wall and to attempt to determine the construction at a point where there was a bend in the acequia (Fig. 4,a). An interesting bonus was the discovery of a gate which once opened into a stone-lined lateral ditch leading west from the acequia toward the area behind the Commander's House. Smal1 fragments of the wooden water-gate posts still remained in the stones on either side of the opening (Figs. 3 and 4). A plug of concrete had at some time been poured into the opening of the gate in order to close it (Fig, 4,b).

Encouraged by this bit of information, the crew then cleaned out the bottom of a backhoe test pit (Fig. 2, Area C) to determine the depth and construction of the bottom of the acequia. At this point, the floor of the acequia is $105 \mathrm{~cm}$ below the present top of the walls, which have been capped by a thin layer of cement. Unfortunately, there is no way to determine the original height of 


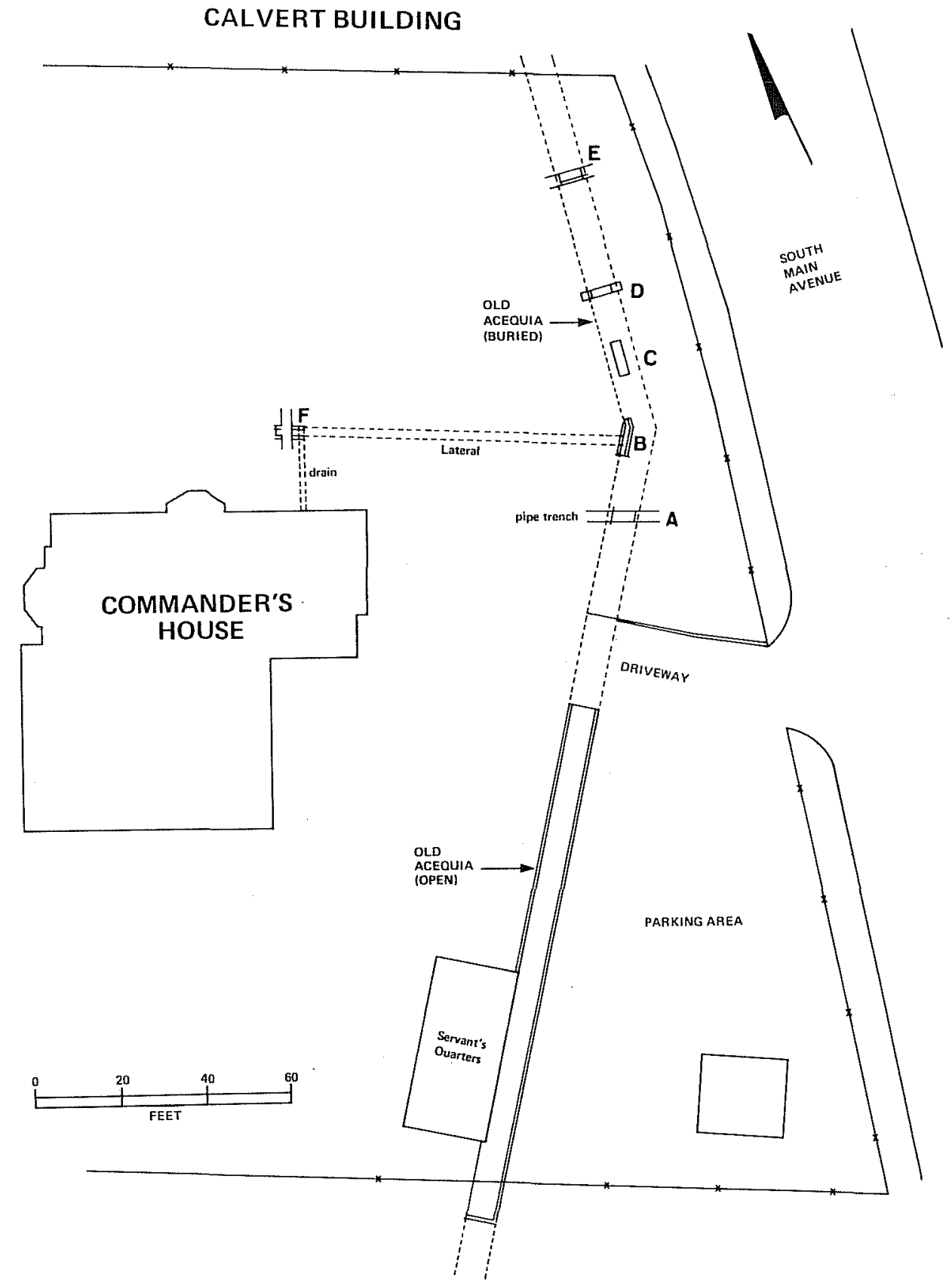

Figure 2. San Pedro Acequia on Grounds of oed Arsenal. Areas of excavations (Areas A-F) are shown. 

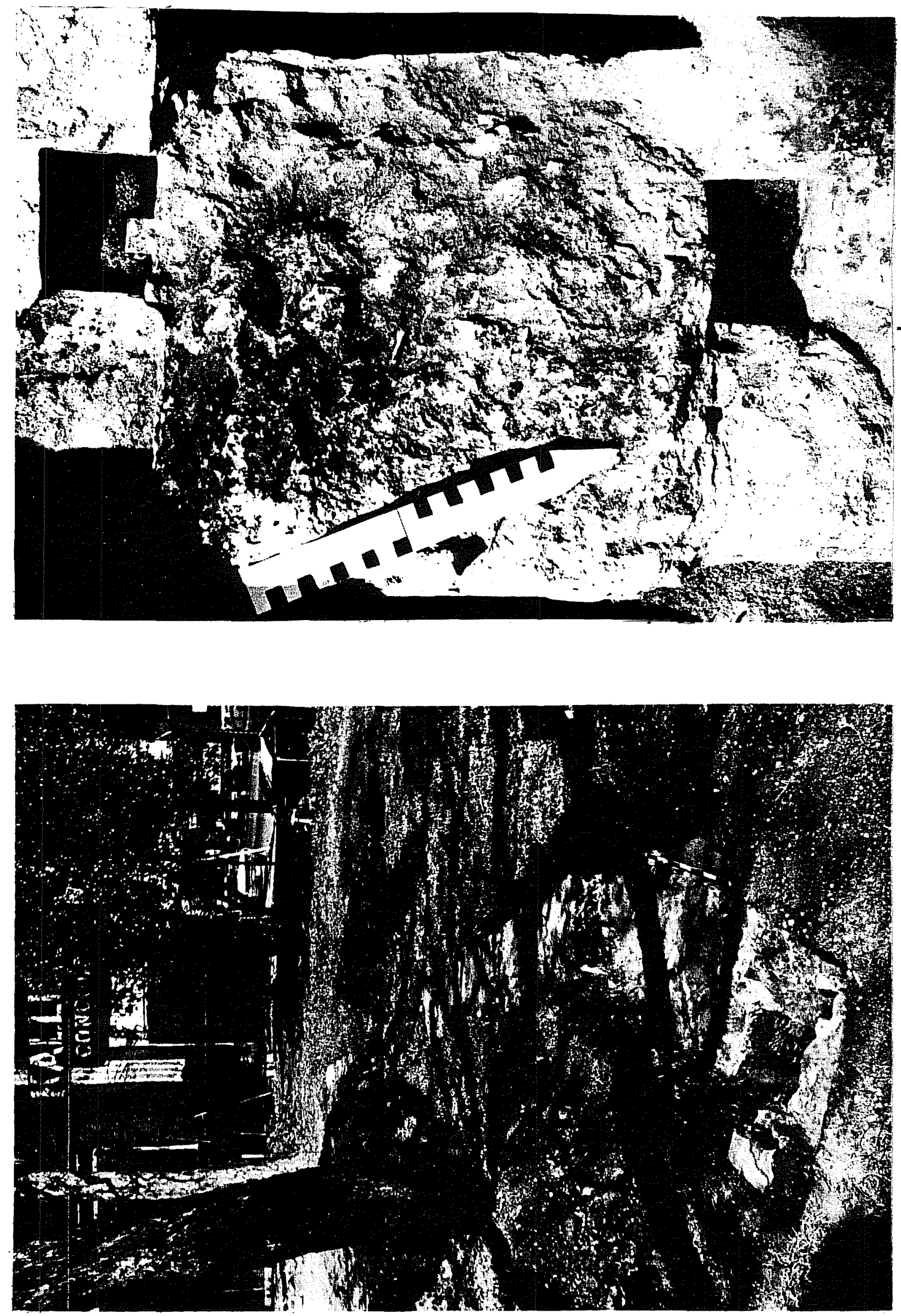
the acequia walls. The floor of the acequia appears to be cemented, which may have been done at the same time that the lateral was plugged and the walls capped and lined with cement. The only artifacts present in the ditch were a mule shoe and fragments of marked D'Hanis brick and window glass. These were resting on the bottom in a 4 to 5 inch layer of damp brown loam. The rest of the fill in the ditch was brown loam identical to the topsoil which covered the rest of the area.

Continuing along the acequia, an area to the north (Fig. 2, Area D) was cleared sufficiently to check the wall lines and to confirm their angle. Area $E$ was cleared off with the same intent, but it soon became apparent that a number of things were different in this excavation (Figs. 5 and 6 ). A cross wall appeared which apparently was built to enclose the portion of the ditch to the south, as it is covered on its south side with the same layer of cement which lines the ditch further south (Fig. 6,a). Clearing to the north of this wall revealed another stone-lined lateral gate leading to the east. A significant part of the frame of the wooden gate was still in place, though quite fragile (Fig. 6,b). Although its construction was identical to that of the first gate, this one was a bit wider.

In the course of trenching for water pipes in the area behind the Commander's House, an accumulation of large animal bones had been found, resting on the basal caliche at a depth of $125 \mathrm{~cm}$ below the present surface of the yard. Analysis of these bones by Cristi Assad of the Center staff revealed that they are from bison or cattle, representing a number of different individuals of various ages. One bone appears cut by a sharp object, but the marks are not diagnostic of any particular type of tool or time period. The depth at which the deposit lay might suggest earlier deposition and that they may have been bison, but no positive conclusion could be reached about how they came to be deposited in this particular spot.

Also found in a pipe trench across this area was the continuation of the stonelined lateral ditch of the acequia. Subsequent clearing and investigation uncovered a drain pipe leading from the house to an opening in the south wall of this lateral ditch (Figs. 2 and 7). Evidently the ditch was used at one time to dispose of rain water from the roof of the early section of the house, which was built in 1859 (Bert Whiteaker, personal communication).

After the archaeological investigation was finished, the contractor filled all excavation areas to protect and preserve the remains of the acequia as much as possible.

\section{Observations}

The section of the main acequia appears to have been cut off at some time by a poured concrete wall. Another identical wall was found just south of the fence behind the Servants' Quarters, southeast of the Commander's House (see Fig. 2). It seems likely that this section of the acequia may have been turned into a fish pond after the acequia was no longer in use, as part of the landscaping scheme of some commanding officer. This could also have provided a reservoir for the rainwater from the roof. In such a case, the concrete plug 


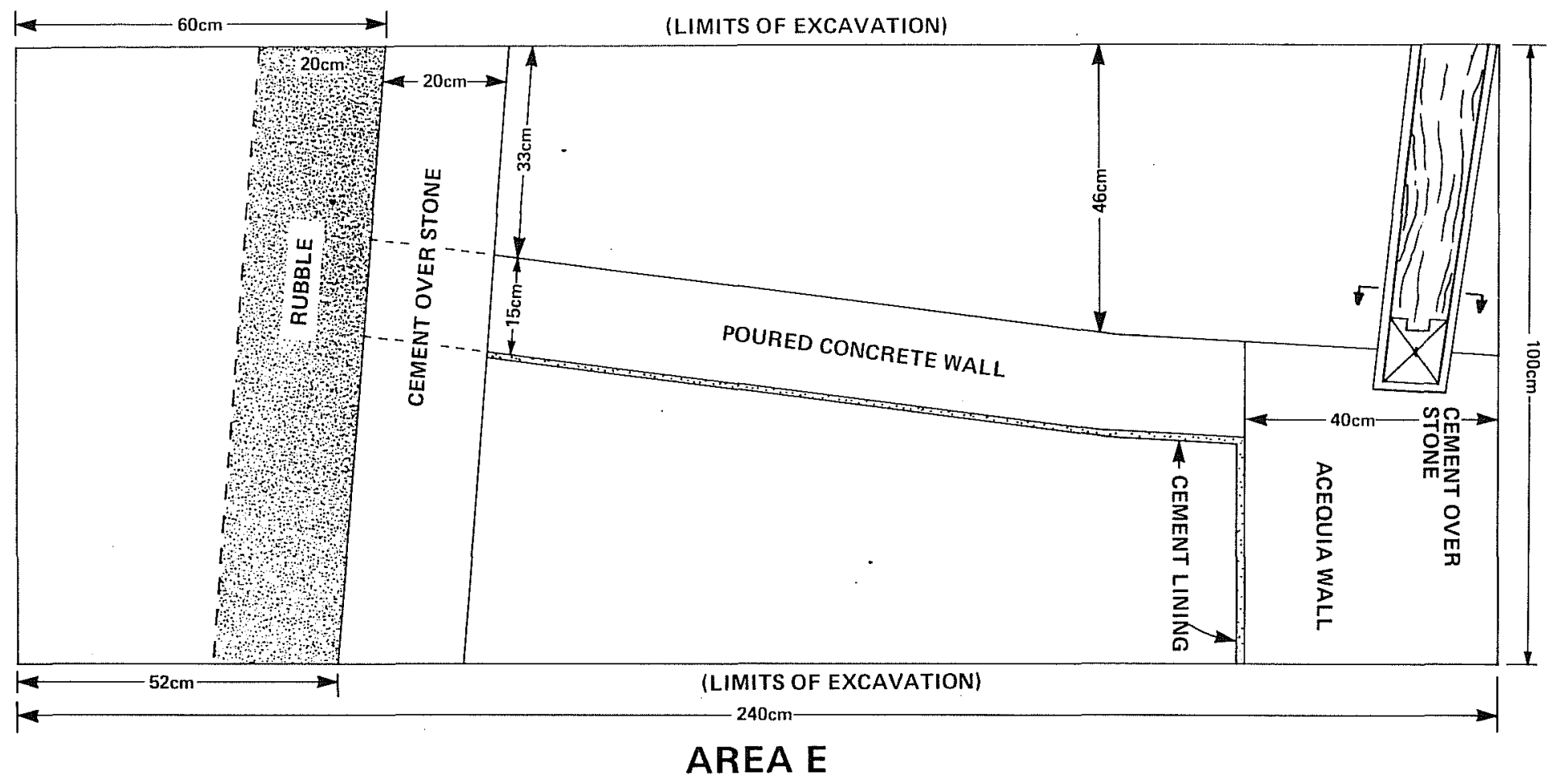

$\hat{i}$

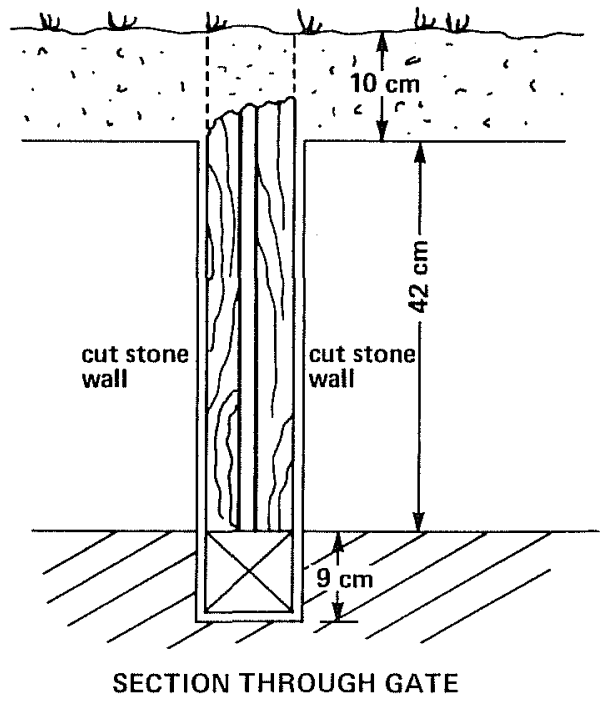

Figure 5. San Pedro Acequia, Area E. Plan and section of lateral gate. 

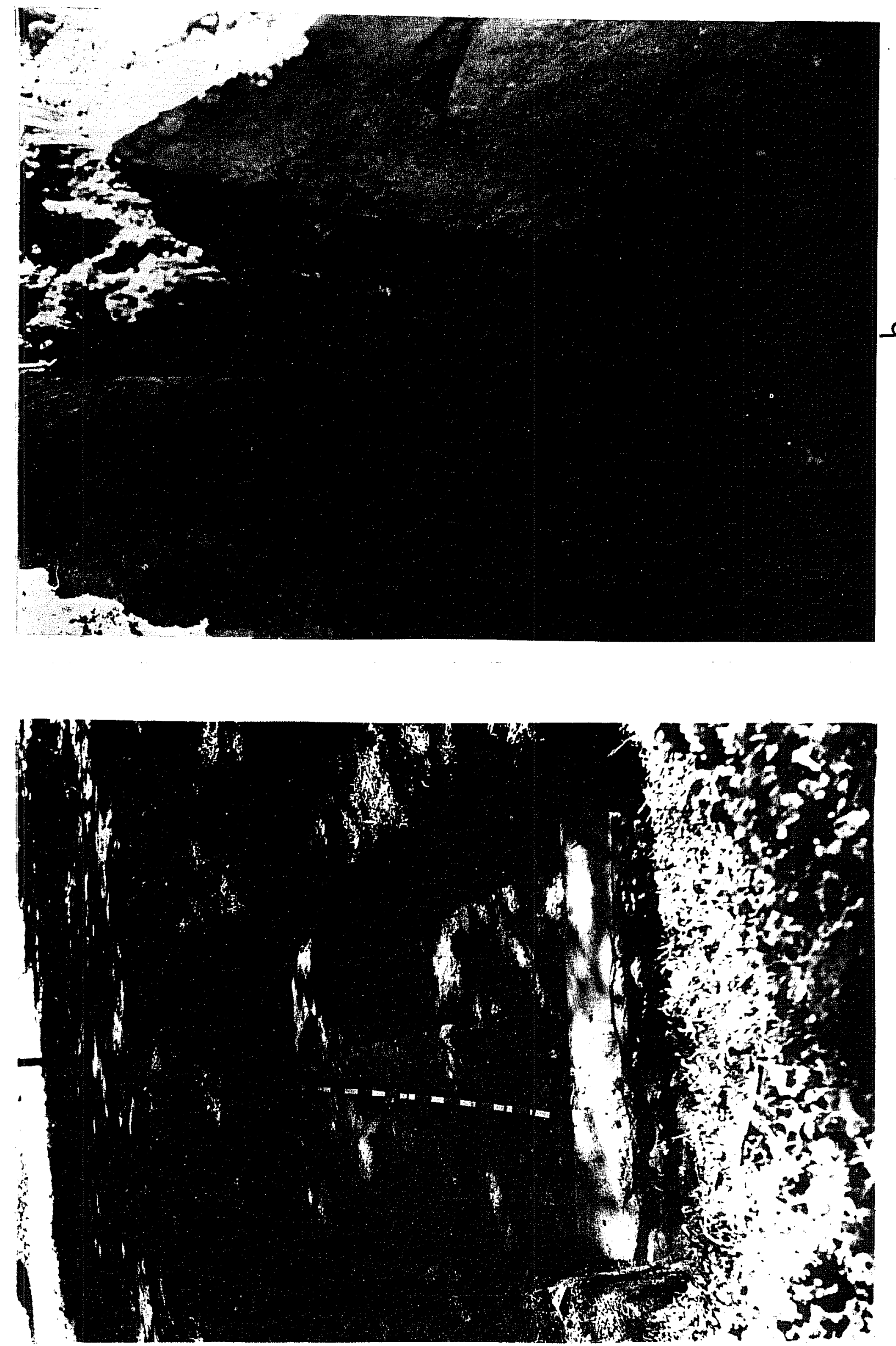


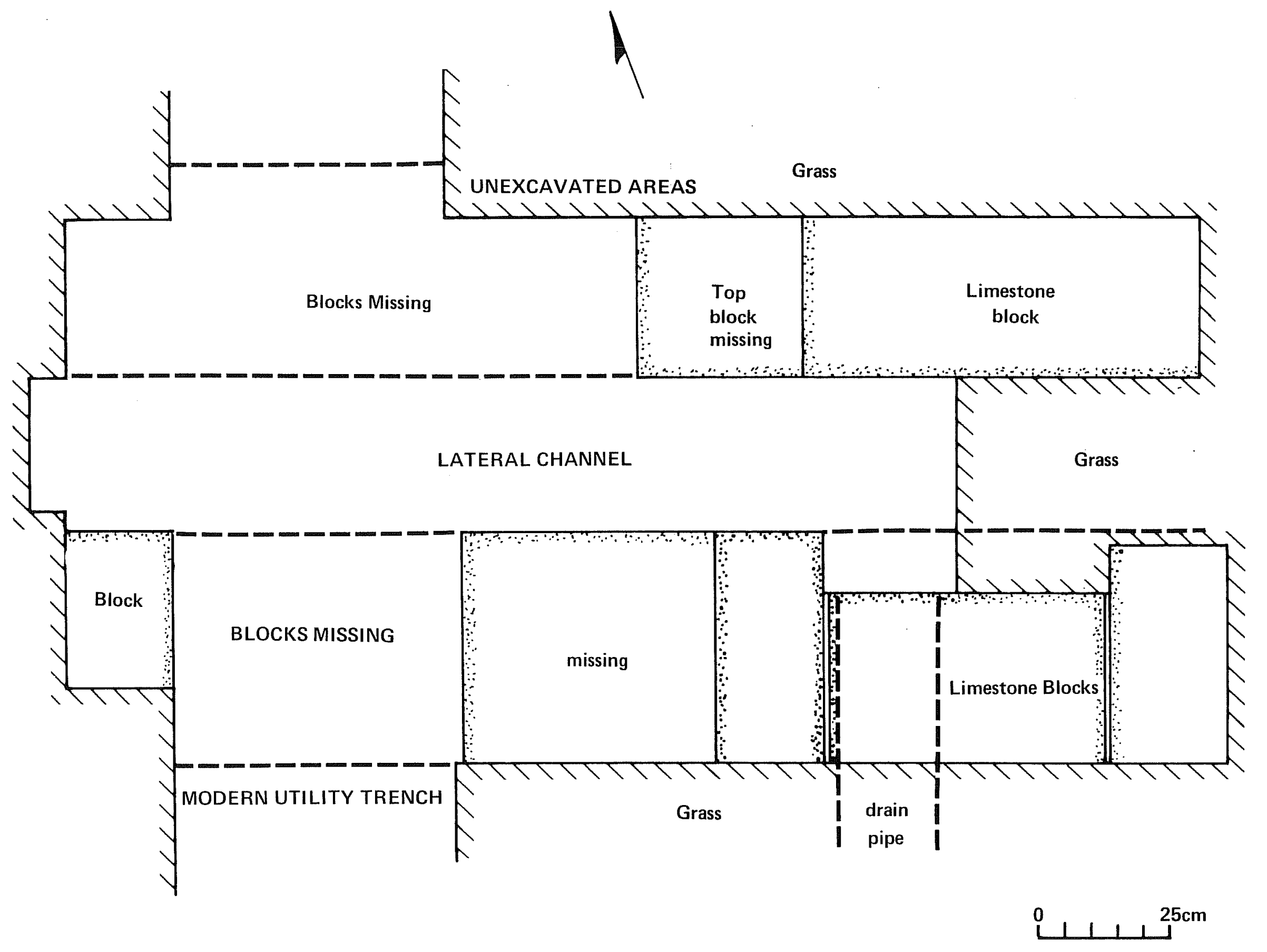


in the lateral gate would have been a later piece of remodeling. Presently the acequia is covered by the lawn on the north side of the driveway, and used as a flower garden on the south side. It is interesting to note that the brick found on the bottom of the acequia is stamped "D'Hanis," a mark not.used until 1905 (John Nester, personal communication), indicating that the acequia must have been filled in at some time after that date.

It was also interesting to find that the old Servants' Quarters had been built using one wall of the acequia as a foundation. This is the same practice found at the Zilker house in 1968 (Schuetz 1970:15).

Investigations at San Pedro Park

In June 1977, the author directed the excavation of a small portion of the Alazan acequia around the head of the springs at San Pedro Park. The work was accomplished primarily by a backhoe operated by a city crew. When most of the fill had been removed by machine, the rest was carefully cleaned out by hand. Then the area was photographed and documentary drawings were made of the construction of the acequia (Fig. 8).

The stonework of the original acequia is similar to that found in other acequias in San Antonio (Schuetz 1970). An additional two courses of cut 1 imestone have been added to the south wall and three to the north wall at some time after the original ditch was built. A coating of cement has been applied to the south wall over the later additions and lapping onto the floor, which is bedrock. The older portion of the walls is set in a crumbling, sandy lime mortar typical of late 19th century stone construction in south Texas.

The acequia was first filled to the $3 / 4$ level with gray clay, which apparently sat open to the weather for some time. On top of this a thin layer of waterborne sand accumulated. Then a layer of gravelly soil was added, into which were set a series of cut limestone blocks which appear to have been salvaged from another structure. Above this a fill of brown loamy topsoil containing late 19th century artifacts was added, to entirely cover and eliminate the ditch. Research into the history of park improvements would probably reveal the dates for these changes.

After this section of the acequia had been thoroughly examined and documented, it was refilled in preparation for a landscaping project in the area.

\section{Observations}

Evidently $\mathrm{Mr}$. Giraud attempted to copy the construction of the other earlier acequias in town when he planned the Alazan acequia. It would be interesting to know if the additional courses of stone on the south wall were added in an attempt to correct the problems mentioned by Corner. The addition of the cement lining on the south wall may also have been part of this work. Additional research in the records of City government agencies might tell more about these problems and the attempts to correct them. 


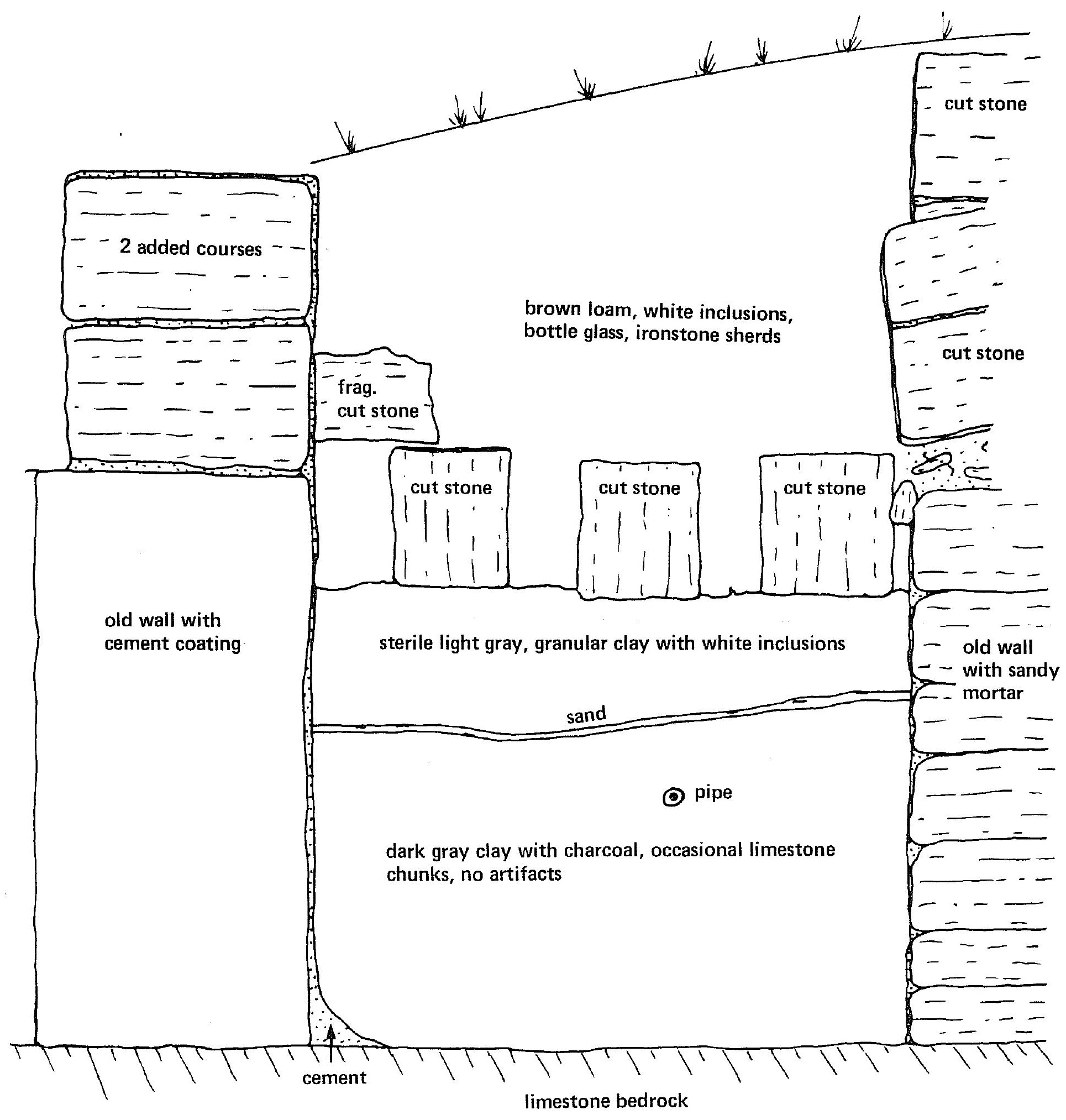

CROSS SECTION-ALAZAN ACEQUIA

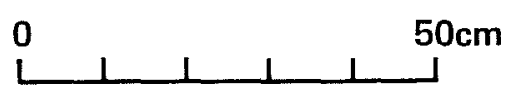

Figure 8. Alazan Acequia. Section looking west. 


\section{CONCLUSIONS AND RECOMMENDATIONS}

Judging from the results of archaeological investigations, large sections of the acequias of San Antonio are still present beneath the ground throughout the city. In many cases, as at the Zi1ker property (Schuetz 1970:14-17), sewer lines have been laid within them. Other sections were used for storm drains, as was the section of the San Pedro acequia which runs in front of San Fernando church (personal observation). Occasionally sections have been given other uses, such as those found on the Arsenal property. Although the top courses of stone may have been removed for use in later buildings, chances are good that at least a trace of the structure remains.

It would, of course, be impossible to attempt to permanently expose or restore most of the acequia system. However, when a section is found to run through an area where it can be used in a landscaping plan, every attempt should be made to preserve and mark that section as a part of the cultural heritage of San Antonio.

\section{REFERENCES CITED}

Adams, R. E. W. and Thomas R. Hester

1973 Letter to Dr. Fred Wendorf, Chairman, Texas Antiquities Committee, concerning completion of excavations at Mission San Antonio de Valero, November 26.

Arneson, Edwin P.

1921 Early Irrigation in Texas. Southwestern Historical Quarterly $X X V: 127-130$.

Barnes, Charles M.

1910 Combats and Conquests of Immortal Heroes. Guessaz \& Ferlet, San Antonio.

Castañeda, Carlos E.

1936 The Mission Era: The Winning of Texas, 1694-1730. Our Catholic Heritage in Texas. Vo1. II. Von Boeckman-Jones Company, Austin.

Chabot, Frederick C.

1937 With the Makers of San Antonio. Artes Gráficas Press, San Antonio.

Corner, William

1890 San Antonio de Bexar. Bainbridge and Corner, San Antonio. 
Crook, Cornelia E.

1967 San Pedro Springs Park, Texas Ozd Recreation Area. Private printing, San Antonio.

Heusinger, Edward $\mathrm{W}$.

1951 A Chronology of Events in San Antonio. Standard Printing Company, San Antonio.

Holmes, William H.

1962 The Acequias of San Antonio. Masters thesis, St. Mary's University, San Antonio.

McLean, Bert J.

1924 The Romance of San Antonio's Water Supply and Distribution System. San Antonio Printing Company.

Minor, Joseph E. and Malcolm L. Steinberg

1968 A Brief on the Acequias of San Antonio. The San Antonio Branch of the Texas Section, American Society of Civil Engineers.

Schuetz, Mardith K.

1970 Excavation of a Section of the Acequia Madre in Bexar County, Texas, and Archaeological Investigations at Mission San Jose in Apri1 1968. Texas Historical Sumey Conmittee, Archeological Report 19 . 